\title{
Pemanfaatan Energi Terbarukan untuk Pembangkit Listrik Tenaga Surya Berbasis Komunitas: Menuju Desa Mandiri Energi
}

\author{
Elvira Sukma Wahyuni, Husein Mubarok, Firmansyah Nur Budiman, Setyawan \\ Wahyu Pratomo \\ Universitas Islam Indonesia Yogyakarta \\ E-mail: elvira.wahyuni@uii.ac.id
}

\section{Article History:}

Received: Jun $13^{\text {th }} 2020$

Revised: Sept $15^{\text {th }} 2020$

Accepted: Nov 30th 2020

Keywords: renewable energy, solar panels, energy independent village.

\begin{abstract}
Located on the equator, Indonesia is blessed with abundant sunlight. With current advances in solar cell and photovoltaic technology, sunlight can be exploited on a large scale, among other things, to be converted into electricity. This paper reports the results of the community service with a focus on the energy sector that took place in Wonosalam Hamlet. The method used was Community Based Research (BCR), where there are three stages of service, namely providing education to the local community about the benefits of sunlight and its use using photovoltaic, photovoltaic installation, and a feasibility study. The results show that with the current usage pattern, a dedication project of IDR 10,000,000 can save energy by $0.48 \mathrm{kWh}$ / day, which is equivalent to around IDR 258,241.28 / year. In addition to the economic benefits that may not bring significant benefits, the broader impact of this project is expected to have an impact on how local people view the use of solar energy as an alternative energy source.
\end{abstract}

\section{Pendahuluan}

Diluar kondisi keandalan pasokan listrik dari PLN, berbagai analisis menyebutkan bahwa energi terbarukan akan menjadi kebutuhkan di masa yang akan datang ${ }^{1}$. Hal ini berkaitan dengan ketersediaan energi fosil yang semakin menipis. ${ }^{2}$ Namun, awareness akan pentingnya energi terbarukan masih sangat rendah di kalangan masyarakat umum. Ditambah lagi dengan kesan bahwa investasi awal untuk memanfaatkan energi terbarukan sangat mahal. Oleh karena itu, perlu adanya pengenalan yang masif kepada

1 Supapo, Santiago, and Pacis, "Electric Load Demand Forecasting for Aborlan-Narra-Quezon Distribution Grid in Palawan Using Multiple Linear Regression," in 9th International Conference on Humanoid, Nanotechnology, Information Technology, Communication and Control, Environment and Management (HNICEM), 2017; Martha Maulidia et al., "Rethinking Renewable Energy Targets and Electricity Sector Reform in Indonesia: A Private Sector Perspective," Renewable and Sustainable Energy Reviews 101 (March 1, 2019): 231-247; Hilman S. Fathoni, Abidah B. Setyowati, and James Prest, "Is Community Renewable Energy Always Just? Examining Energy Injustices and Inequalities in Rural Indonesia," Energy Research \& Social Science 71 (January 1, 2021): 101825.

2 Djoni Hartono et al., "Comparing the Impacts of Fossil and Renewable Energy Investments in Indonesia: A Simple General Equilibrium Analysis," Heliyon 6, no. 6 (June 1, 2020): e04120. 
masyarakat mengenai manfaat energi terbarukan. Dari permasalahan ini adalah suplay energi fosil yang terus menipis tersebut sehingga penggunaan energi terbarukan harus sedini mungkin diperkenalkan ke masyarakat luas, agar ketika suplay energi fosil benarbenar sudah tidak mampu mencukupi kebutuhan masyarakat, masyarakat sudah siap dengan kemandirian energi di desanya masing-masing.

Pelanggan listrik residensial atau rumah tangga adalah pelanggan listrik PLN yang cukup berperan penting dalam upaya penyediaan energi listrik. Pelanggan rumah tangga adalah salah satu pelanggan terbesar dalam keseluruhan pelanggan listrik di Indonesia. ${ }^{3}$ Dengan demikian, harapannya adalah pelanggan rumah tangga memiliki performa yang baik dalam proses penyediaan dan pemanfaatan energi listrik. Hal ini dapat diukur dengan melihat nilai faktor beban dan faktor kebutuhan yang ada. ${ }^{4}$ Namun pada kenyataannya, sebagian besar pelanggan rumah tangga memiliki performa yang kurang baik. Hal ini disebabkan oleh perilaku (behavior) pelanggan yang kurang baik dalam pemanfaatan energi listrik.

Salah satu contohnya adalah, tidak sedikit pelanggan yang tidak memahami konsep Waktu Beban Puncak (WBP) ${ }^{5}$ dan Luar Waktu Beban Puncak (LWBP) ${ }^{6}$. Sehingga banyak pelanggan yang tidak memanfaatkan konsep Manajemen Beban (Load Management). ${ }^{7}$ Contohnya, tidak sedikit pelanggan yang menyetrika di malam hari, menghidupkan pemanas dispenser meski tidak digunakan, dan tidak sedikit pelanggan rumah tangga yang memiliki daya terpasang $2200 \mathrm{VA}$, namun penggunaan riilnya tidak mencapai 1000 Watt karena alasan rumah jarang dihuni dan lain sebagainya. Tentu hal ini akan menyumbang buruknya nilai faktor kebutuhan.

Oleh karena itu, pendidikan akan perilaku pengguna energi (behaviour) sangat diperlukan. Di sisi lain, untuk menghemat penggunaan energi listrik dari PLN, pelanggan dapat memasang energi alternatif terbarukan. Terciptanya desa mandiri energi merupakan tujuan utama untuk mengurangi ketergantungan konsumsi energi listrik negara. Salah satu energi terbarukan yang dapat dimanfaatkan sebagai sumber energi

3 Ibid.

4 Winita Sulandari et al., "Indonesian Electricity Load Forecasting Using Singular Spectrum Analysis, Fuzzy Systems and Neural Networks," Energy 190 (January 1, 2020): 116408.

${ }^{5}$ Ralph M. Braid, "Partial Peak-Load Pricing of a Transportation Bottleneck with Homogeneous and Heterogeneous Values of Time," Economics of Transportation 16 (December 1, 2018): 29-41.

6 Sukandarrumidi, Herry Zadrak Kotta, and Djoko Wintolo, Energi Terbarukan Konsep Menuju Kemandirian Energi (Yogyakarta: Gadjah mada university press, 2018); Christopher Winstead et al., "Peak Load Reduction and Load Shaping in HVAC and Refrigeration Systems in Commercial Buildings by Using a Novel Lightweight Dynamic Priority-Based Control Strategy," Applied Energy 277 (November 1, 2020): 115543.

7 Ahmed G. Ismail, Mahmoud A. El-Dabah, and Ibrahim A. Nassar, "Enhancement of Electrical Distribution Networks Performance Using the Load Management Methodology," Energy Reports 6 (November 1, 2020): 2066-2074; Morteza Zare Oskouei et al., "Practical Implementation of Residential Load Management System by Considering Vehicle-for-Power Transfer: Profit Analysis," Sustainable Cities and Society 60 (September 1, 2020): 102144. 
alternatif adalah pemanfaatan tenaga surya (solar cell). ${ }^{8}$ Solar Cell atau yang sering dikenal sebagai Panel Surya merupakan sebuah pembangkit energi listrik terbarukan yang mulai banyak digunakan dalam beberapa tahun terakhir. Panel surya merupakan pembangkit listrik yang memanfaatkan energi matahari sebagai sumber energi utamanya9. Sumber energi surya merupakan merupakan salah satu sumber energi alternatif yang paling memungkinkan atau masuk akal secara ekonomi dan merupakan salah satu solusi dalam techno-economic untuk listrik bagi daerah pedesaan 10,11,12. Pemanfaatan solar sebagai sumber ernergi terbarukan memiliki nilai investasi yang cenderung sama dengan sumber energi terbarukan lain seperti angin, namun memiliki sedikit kekurangan yaitu memiliki waktu pengembalian nilai investasi yang lebih lama ${ }^{13}$.

Wacana pengembangan solar cell untuk mememenuhi kebutuhan listrik masyarakat mengerucut pada penerapan solar cell untuk rumah tangga. ${ }^{14}$ Namun pengetahuan masyarakat mengenai sumber energi terbarukan boleh dikatakan sangat minim, untuk mewujudkan desa mandiri energi tentu saja perlu adanya sosialisasi dan edukasi kepada masyarakat. Salah satu permasalahan utama yang mengakibatkan masyarakat tidak mau bahkan sulit beralih dari sumber energi fosil adalah nilai investasi ${ }^{15}$. Dengan keterbatasan pengetahuan masyarakat, mereka beranggapan penggunaan solar cell sebagai sumber energi sangat mahal, padahal menurut analisis kelayakan pemanfaatan solar cell dapat menekan cost biaya listrik secara signifikan ${ }^{16,17}$.

${ }^{8}$ Armi Tiihonen et al., "Biocarbon from Brewery Residues as a Counter Electrode Catalyst in Dye Solar Cells," Electrochimica Acta 368 (February 1, 2021): 137583; Prasanth K. Enaganti et al., "Analysis of Submerged Amorphous, Mono-and Poly-Crystalline Silicon Solar Cells Using Halogen Lamp and Comparison with Xenon Solar Simulator," Solar Energy 211 (November 15, 2020): 744-752. Press, 2017)

9 Wibawa Unggul, Pendekatan Praktis Pembangkit Energi Baru Dan Terbarukan (Bandung: UB

10 Jim Esch, "Keeping the Energy Debate Clean: How Do We Supply the World's Energy Needs?," Proceedings of the IEEE 98, no. 1 (2010): 39-41.

${ }^{11}$ Karen Ubilla et al., "Smart Microgrids as a Solution for Rural Electrification: Ensuring Long-Term Sustainability through Cadastre and Business Models," IEEE Transactions on Sustainable Energy 5, no. 4 (2014): 1310-1318.

12 Madalsa Singh and P. Balachandra, "Microhybrid Electricity System for Energy Access, Livelihoods, and Empowerment," Proceedings of the IEEE 107, no. 9 (2019): 1995-2007.

13 Mariano Arriaga, Claudio A. Canizares, and Mehrdad Kazerani, "Renewable Energy Alternatives for Remote Communities in Northern Ontario, Canada," IEEE Transactions on Sustainable Energy 4, no. 3 (2013): 661-670.

14 Towhidul Islam and Nigel Meade, "The Impact of Attribute Preferences on Adoption Timing: The Case of Photo-Voltaic (PV) Solar Cells for Household Electricity Generation," Energy Policy 55, Special section: Long Run Transitions to Sustainable Economic Structures in the European Union and Beyond (April 1, 2013): 521-530. 2017).

15 Yuliarto Briyan, Pendekatan Praktis Pembangkit Energi Baru Dan Terbarukan (Bandung: ITB,

${ }^{16}$ Abhishek Kumar et al., "A Novel Methodological Framework for the Design of Sustainable Rural Microgrid for Developing Nations," IEEE Access 6 (2018): 24925-24951.

17 Abubakr S. Bahaj and Patrick A.B. James, "Electrical Minigrids for Development: Lessons from the Field," Proceedings of the IEEE 107, no. 9 (2019): 1967-1980. 
Periode sebuah biaya investasi tertutup atau Payback Period sering menjadi perhatian utama pada sebuah investasi. ${ }^{18}$ Masyarakat awam pada umunya akan berpikir bahwa pengembalian modal pada pemasangan panel surya akan berlangsung lama. Hal ini akan sangat wajar dan menjadi pemikiran umum, dikarenakan masyarakat sudah mengetahui bahwa panel surya memiliki biaya investasi yang cukup tinggi. Sebenarnya, payback period hanyalah langkah awal dalam memperoleh keuntungan bersih. Pemikiran-pemikiran yang kurang tepat pada masyarakat awam ini harus diluruskan. Oleh karena itu masyarakat juga harus diedukasi mengenai nilai invesatasi berdasarkan bahaviour pengunaan energi dan penghitungan payback period untuk pemanfaatan solar cell, sehingga tewujudnya desa mandiri energi.

Dalam salah satu bidang fokusnya, Teknik Elektro dan FTI UII memberi perhatian khusus mengenai pengembangan energi terbarukan. Sebagai buktinya, tim dari Teknik Elektro UII terlibat aktif dalam pemasangan panel surya di Gedung KH Mas Mansur FTI UII. Dan sebagai bentuk usaha untuk lebih menyebarluaskan pengetahuan dan implementasi energi terbarukan, khususnya energi matahari, tim dari Teknik Elektro bermaksud untuk mengadakan sosialisasi dan pemasangan prototype panel surya di masyarakat sekitar UII yang diwujudkan dalam bentuk pengabdian kepada masyarakat. Tujuan pengabdian ini adalah memperkenalkan, memasang dan mensupervisi penggunaan energi surya sebagai sumber energi listrik, serta mewujudkan masyarakat yang mandiri energi.

Wilayah yang akan menjadi target pengabdian ini adalah Dusun Wonosalam, Desa Sukoharjo, Kec. Ngaglik, Sleman. Dusun ini merupakan kawasan pedesaan yang terletak di sekitar UII. Sebagaimana di mayoritas kawasan lain, penetrasi energi terbarukan masih nol di dusun ini, sehingga masih terbuka lebar kesempatan untuk melakukan pengabdian masyarakat di bidang energi terbarukan.

\section{Metode}

Metode yang digunakan pada riset pengabdian ini adalah Community-based research (CBR). CBR adalah pendekatan yang digunakan oleh para peneliti dalam kemitraan dengan praktisi dan anggota komunitas untuk mengatasi masalah sosial yang kompleks demi kemajuan masyarakat ${ }^{19}$. Subjek riset pengabdian ini adalah warga masyarakat Dusun Wonosalam, Desa Sukoharjo, Kecamatan Ngaglik, Kabupaten Sleman, Yogyakarta

${ }^{18}$ Akvile Lawrence et al., "Effects of Monetary Investment, Payback Time and Firm Characteristics on Electricity Saving in Energy-Intensive Industry," Applied Energy 240 (April 15, 2019): 499-512.

${ }^{19}$ Naim Kapucu, "Community-Based Research in Generating Usable Knowledge for Public Policy and Administration," Sage Journals 48, no. 6 (2014): 683-710. 
Tahapan kegiatan pengbdian yang dilaksanakan dijelaskan melalui diagram alir pengabdian pada gambar 1 . Tahapan pertama yang dilakukan pengabdi adalah analisis situasi pada desa mitra terkait dengan pengembangan desa mandiri energi, pada pengabdian ini pengabdi memilih Dusun Wonosalam sebagai desa mitra, alasan pemilihannya adalah karena berdekatan dengan kampus UII sehingga pengabdi dapat melakukan kontrol lebih mudah.

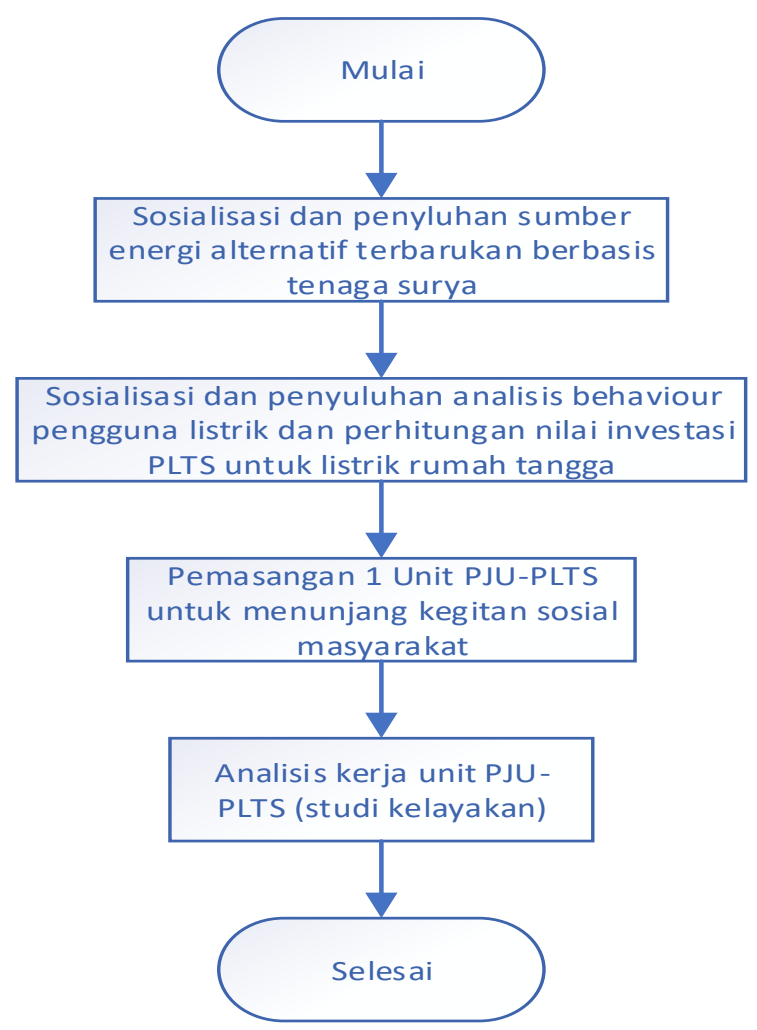

Gambar 1. Diagram Alir Pengabdian

Selanjutnya pengabdi yang diwakili oleh ketua pengabdian melakukan korespondensi dengan pejabat setempat (Dukuh dan RT) mengenai kegiatan pengabdian yang akan dilakukan. Kemudian tim melakukan diskusi terkait kegiatan pengabdian yang akan dilakukan, adapun rincian kegiatan akan dijelaskan sebagai berikut.

Kegiatan 1: Sosialisasi dan penyuluhan sumber energi alternatif terbarukan berbasis tenaga surya. Kegiatan ini bertujuan untuk memberikan pengetahuan dan mengedukasi masyarakat mengenai sumber energi alternatif dan sumber energi terbarukan. Pada kegiatan ini masyarakat akan dikenalkan dengan sumber energi berbasis tenaga surya/matahari.

Kegiatan 2: Sosialisasi dan penyuluhan analisis behaviour pengguna listrik dan perhitungan nilai investasi PLTS untuk listrik rumah tangga. Kegiatan ini bertujuan untuk 
memberikan jasa konsultasi mengenai pemasangan PLTS untuk rumah tangga, mulai dari analisis behaviour pengguna, konsep PLTS, desain pemasangan dan perhitungan nilai investasi yang harus dikeluarkan. Selain itu, kegiatan ini juga menjelaskan mengenai pay back period.

Kegiatan 3: Pemasangan 1 Unit PJU-PLTS untuk menunjang kegiatan sosial masyarakat. Kegiatan ini bertujuan memberikan percontohan pemasangan PLTS kepada masyarakat. Pemasangan PLTS akan dilakukan di tempat kegiatan sosial masyarakat (contohnya: masjid)

Kegiatan 4: Analisis kerja Unit PJU-PLTS (studi kelayakan). Kegiatan ini bertujuan untuk melakukan supervisi dan studi kelayakan pemasangan PLTS di desa mitra.

\section{Hasil dan Diskusi}

\section{Kegiatan Sosialisasi dan Penyuluhan}

Kegiatan sosilaisasi dan penyuluhan sumber energi terbarukan berbasis panel surya yang dihadiri oleh seluruh kepala keluarga Dusun Wonosalam. Ada dua tema pembahasan utama yang disampaikan, pertama adalah pengenalan sumber energi terbarukan berbasis panel surya dan yang kedua adalah analisis behaviour pengguna listrik dan perhitungan nilai investasi PLTS untuk listrik rumah tangga. Kemudian acara ditutup dengan penyerahan secara simbolis satu unit PJU-PLTS untuk Dusun Wonosalam.
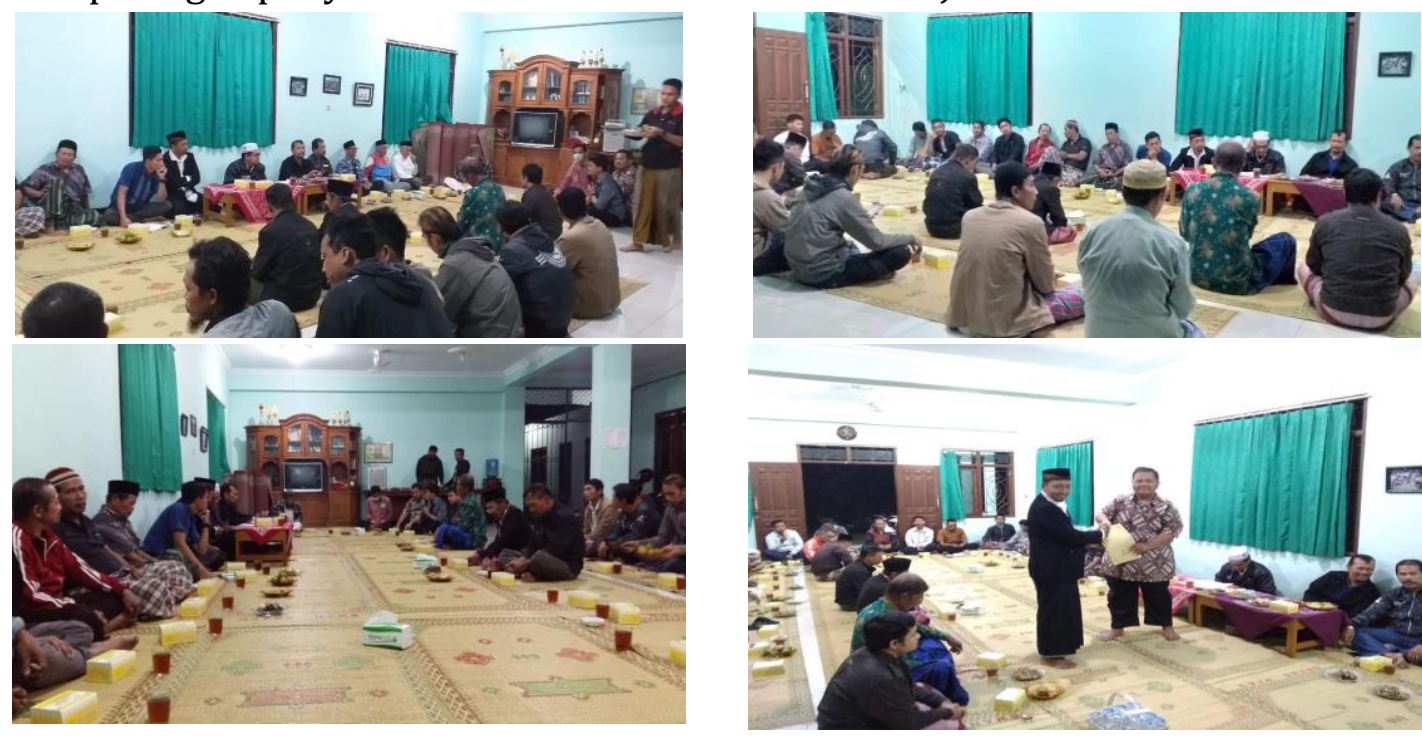

Gambar 2. Dokumentasi kegiatan sosialisasi dan penyuluhan

\section{Pemasangan PJU PLTS}

Pemasangan PJU-PLTS dibantu oleh warga masyarakat Dusun Wonosalam 
terutama dalam penanaman tiang PJU. Kemuadian instalasi PJU-PLTS dilakukan oleh teknisi tim pengabdi, dan alahamdulillah PJU-PLTS telah beroperasi dengan baik sampai saat ini.
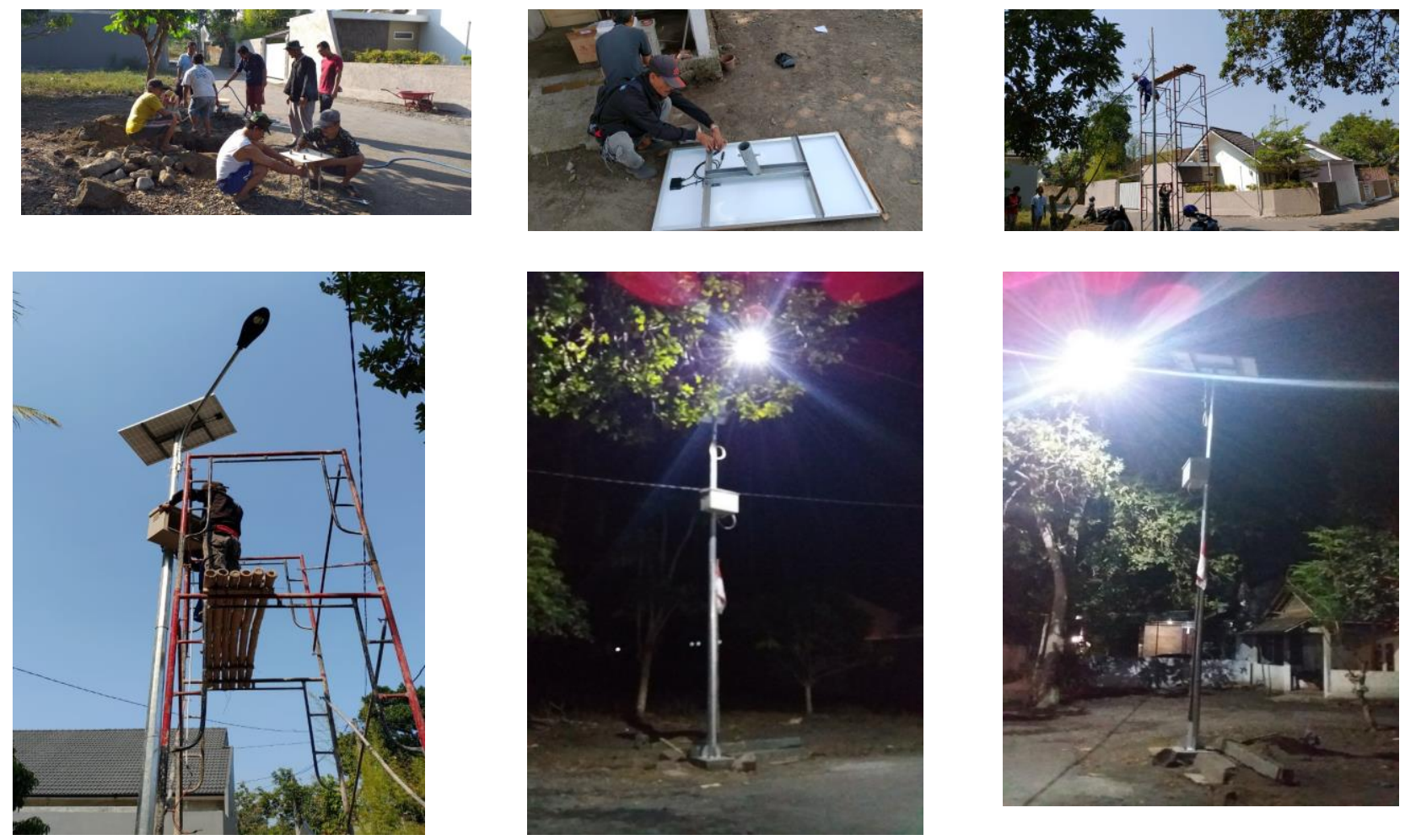

Gambar 3. Dokumentasi pemasangan PJU PLTS

\section{Studi Kelayakan Sistem Hybrid Solar Cell-Grid Di Desa Wonosalam}

\section{Desain Sistem}

Skematik dari sistem Hybrid yang dirancang di Desa Wonosalam terdiri atas beberapa komponen, yaitu solar cell, baterai, converter, dan grid. Adapun desainnya dapat dilihat pada gambar 4 sebagai berikut: 


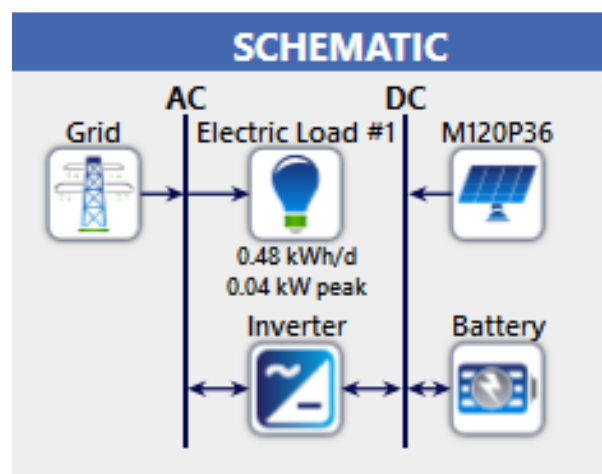

Gambar 4. Desain skematik sistem PV-Grid

\section{Komponen Penyusun Sistem PLTS}

\section{Solar Cell}

Solar cell yang digunakan dalam sistem Hybrid ini adalah tipe CS6P-260P dari Canadian Solar. Solar cell ini terdiri dari 24 pcs palet yang berkapasitas maksimum hingga $260 \mathrm{~W}$ dan dapat digunakan hingga 25 tahun lamanya.

\section{Inverter}

Inverter yang digunakan dalam sistem Hybrid ini adalah Luminous Solar 750 VA sebanyak 1 buah dengan kapasitas $450 \mathrm{~W}$. Selain bekerja sebagai inverter, konverter ini juga mampu memberikan back up beban pada sistem hingga 10 jam. Adapun umur penggunaan dari inverter ini adalah 10 tahun

\section{Baterai}

Baterai yang digunakan dalam sistem ini adalah Luminous Battery 150 Ah - RC18000 sebanyak 1 buah. Jenis dari baterai ini adalah tubular dan dapat digunakan hingga 10 tahun.

\section{Grid}

Grid merupakan jaringan PLN yang dalam sistem ini menggunakan fungsi Net Metering. Artinya, ketika solar cell memproduksi daya berlebih maka kelebihan daya tersebut akan diekspor ke PLN untuk dapat digunakan pada bulan berikutnya, sehingga dapat mengurangi biaya tagihan listrik pada bulan yang akan datang. Harga beli listrik atau biaya impor energi ke PLN adalah Rp1.467.28/kWh dan harga jual atau biaya ekspor Rp 952.732/kWh.

\section{Parameter yang digunakan}

\section{Radiasi Matahari}

Data radiasi matahari yang digunakan dalam sistem Hybrid ini diperoleh dari situs NASA. 
Rata-rata radiasi matahari per bulannya dapat dilihat pada tabel 1 sebagai berikut.

Tabel 1. Data Radiasi Per Bulan

\begin{tabular}{ll}
\hline Bulan & Radiasi Harian $\left(\mathrm{kWh} / \mathrm{m}^{2} / \mathrm{d}\right)$ \\
\hline Januari & 4,28 \\
Februari & 4,47 \\
Maret & 4,59 \\
April & 4,72 \\
Mei & 4,73 \\
Juni & 4,55 \\
Juli & 4,80 \\
Agustus & 5,25 \\
September & 5,54 \\
Oktober & 5,39 \\
November & 4,71 \\
Desember & 4,57 \\
\hline
\end{tabular}

\section{Data Beban}

Data beban yang digunakan dalam simulasi sistem Hybrid ini diperoleh dari pendataan peralatan elektronika yang biasa digunakan di pos ronda. Setelah data beban diperoleh, berikutnya di input ke software HOMER untuk nantinya disimulasikan. Jendela untuk menginput data beban pada software HOMER dapat dilihat pada gambar 5 sebagai berikut.

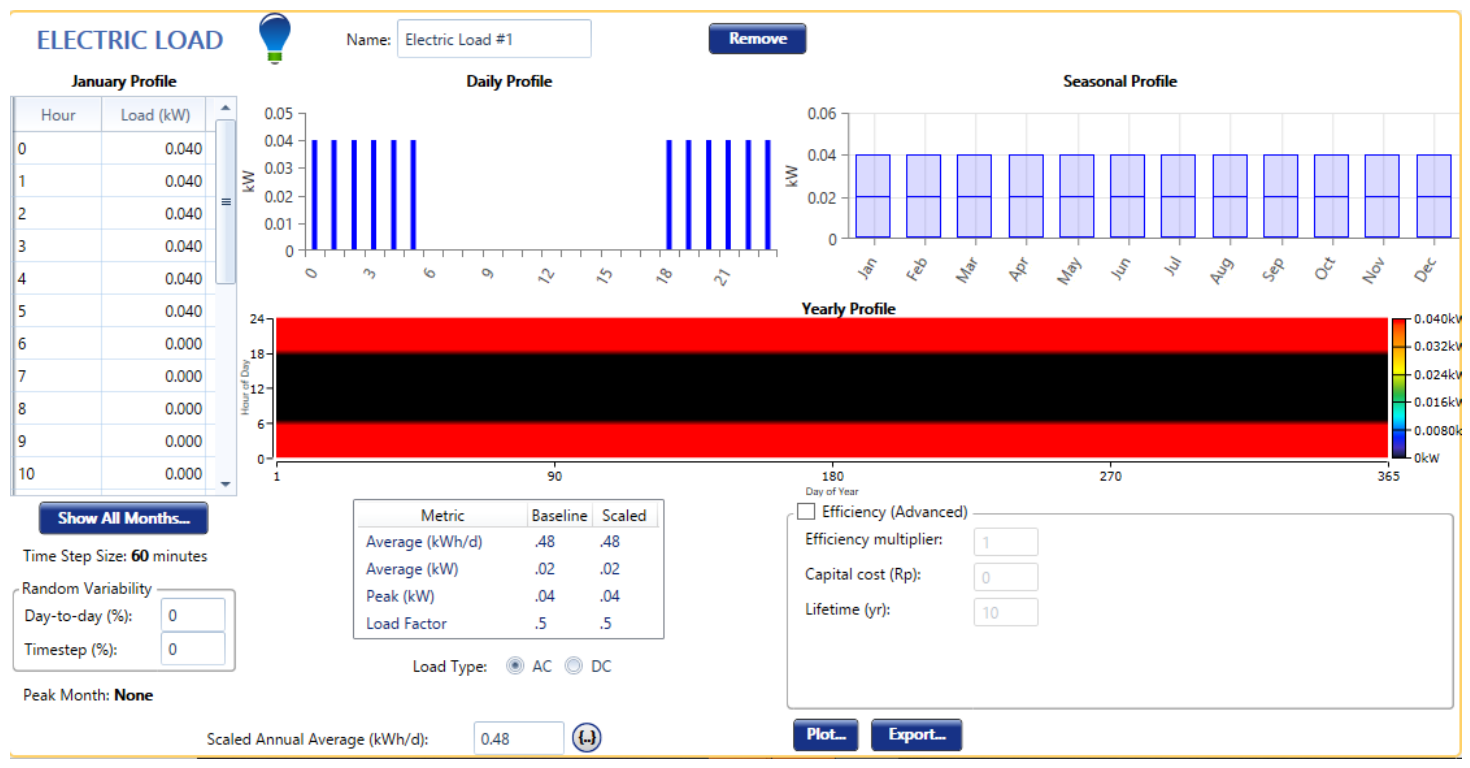

Gambar 5. Jendela Pengaturan Beban 


\section{Pengaruh Parameter terhadap Desain Sistem Hybrid}

Ada 2 parameter yang berperan penting dalam jalannya simulasi sistem Hybrid ini, yaitu radiasi matahari dan data beban. Radiasi matahari berperan penting terkait dengan produksi energi dari solar cell nantinya, guna didapatkan hasil produksi energi dari solar cell yang aktual. Demikian pula dengan data beban, untuk dapat mengetahui apakah sistem yang dirancang mampu menyuplai kebutuhan beban maka dibutuhkan data beban yang diperoleh secara aktual.

\section{Hasil Optimasi Desain Skematik Pembangkit Listrik Tenaga Hybrid}

Hasil optimasi bertujuan untuk mengetahui tingkat variabel komponen utama pada pembangkit listrik tenaga hybrid saat beroperasi. Hasil optimasi ini diperoleh ketika proses simulasi pada software HOMER telah selesai dijalankan. Gambar 6 berikut ini menunjukan hasil optimasi variabel dari masing-masing komponen yang terdapat pada desain sistem Solar Cell-Grid di Desa Wonosalam.

\begin{tabular}{|c|c|c|c|c|c|c|c|c|}
\hline 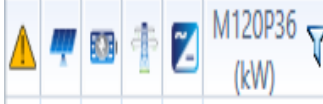 & Battery $?$ & ${ }_{(\mathrm{kM})}^{\text {Grid }} \nabla_{(\mathrm{kW})}^{\text {Inverter }} \nabla$ & Dispatch $\nabla$ & ${ }_{(R p)}^{C O E} \rightarrow$ & ${ }_{(\mathrm{Rp})}^{\mathrm{NPC}} \boldsymbol{P} \mathrm{P}$ & $\underbrace{\text { Operating cost }}_{(\text {Rp/yr) }} \rightarrow P$ & $\begin{array}{c}\text { Initial capital } \\
(R p)\end{array}$ & (xis) $\operatorname{rag} 07$ \\
\hline \pm 0.120 & & $999,9990,450$ & $\mathrm{CC}$ & Rp599,25 & Rp4.24M & $\operatorname{Rp} 72,726$ & Rp2.75M & 49.4 \\
\hline II 0.120 & 1 & $999,9990.450$ & $\mathrm{CC}$ & Rp 1,565 & Rp11.1M & Rp280,956 & Rp5.33M & 49.4 \\
\hline 雨 & 1 & $999,9990.450$ & $C C$ & Rp3,851 & Rp13.8M & Rpt97,500 & Rp3.62M & 0 \\
\hline
\end{tabular}

\section{Total Produksi Energi}

Gambar 6. Hasil Optimasi Sistem Solar Cell-Grid

Total produksi energi yang dihasilkan selama setahun dari sistem pembangkit listrik tenaga hybrid Solar Cell-Grid sebagai penyedia energi listrik masyarakat adalah sebesar $351 \mathrm{kWh} /$ tahun. Hasil dari total produksi energi selama setahun dari sistem pembangkit listrik tenaga hybrid dapat dilihat pada tabel 2 berikut ini.

Tabel 2. Produksi Energi Per Tahun

\begin{tabular}{lll}
\hline Komponen & $\begin{array}{l}\text { Produksi } \\
(\mathrm{kWh}) / \text { tahun }\end{array}$ & Persentase (\%) \\
\hline Tiger World M120P36 & 176 & 50.2 \\
Grid & 175 & 49.8 \\
Total & 351 & 100 \\
\hline
\end{tabular}

Berdasarkan informasi dari tabel 2 di atas, dapat diketahui bahwa total produksi energi listrik pada solar cell lebih besar dari total energi listrik yang disuply dari PLN. Hal ini dikarenakan kapasitas dari solar cell yang lebih besar dari kebutuhan beban, sehingga 
produksi energi dari solar cell yang dikonsumsi beban lebih mendominasi dari suply listrik yang dilakukan oleh PLN.

Berdasarkan kondisi tersebut, dapat dianalisa bahwa sistem tenaga surya yang digunakan sangat tepat dalam mewujudkan energi bersih dan ekonomis di masyarakat. Produksi energi listrik yang dikeluarkan PLN adalah sebesar $175 \mathrm{kWh} /$ tahun atau sebesar 49,8 \% dari total keseluruhan energi. Sedangkan energi yang diproduksi oleh pembangkit tenaga surya adalah $176 \mathrm{kWh} /$ tahun atau senesar 50,2 \%. Hal ini menunjukkan bahwa energi surya yang dipasang mampu menopang kebutuhan masyarakat dengan baik dan mendominasi dalam produksi energi secara keseluruhan.

\section{Net Present Cost (NPC)}

Total NPC dari suatu sistem adalah nilai dari semua biaya yang timbul selama masa pakai, dikurangi nilai sekarang dari semua pendapatan yang diperoleh selama masa pakai. Biaya-biaya tersebut termasuk biaya modal, biaya penggantian, Operasi dan Biaya pemeliharaan, biaya bahan bakar, penalti emisi, dan biaya pembelian listrik dari jaringan. Pendapatan termasuk nilai sisa dan pendapatan penjualan grid $^{20}$. Biaya total yang digunakan untuk komponen dalam proyek pemasangan atau pun pengoperasian pembangkit listrik tenaga hybrid sebesar Rp 9.742.180,31. Adapun rincian dari tiap komponen dapat dilihat pada Tabel 3.

Tabel 3. Rincian Net Present Cost Pada Tiap Komponen

\begin{tabular}{|c|c|c|c|c|c|c|}
\hline Componen & Capital (Rp) & $\begin{array}{l}\text { Replacemnet } \\
\text { (RP) }\end{array}$ & O\&M (Rp) & $\begin{array}{l}\text { Fuel } \\
\text { (Rp) }\end{array}$ & Salvage (Rp) & Total (Rp) \\
\hline $\begin{array}{l}\text { Canadian } \\
\text { Solar CS6P- } \\
260 P\end{array}$ & $3,564,062.5$ & 0.00 & $1,455,276,13$ & 0.00 & 0.00 & $5,019,338.63$ \\
\hline Grid & 0.00 & 0.00 & $3,803,335.30$ & 0.00 & 0.00 & $3,803,335.30$ \\
\hline $\begin{array}{l}\text { Luminous } \\
\text { Battery } \\
150 \mathrm{Ah}- \\
\text { RC } 18000\end{array}$ & $2,576,495,41$ & $4,060,587.35$ & $1,052,033.25$ & 0.00 & $861,402, .34$ & $6,827,713.67$ \\
\hline $\begin{array}{l}\text { Luminous } \\
\text { solar nxg } \\
\text { hybrid } \\
\text { inverter } \\
750 \mathrm{VA}- \\
12 \mathrm{~V}\end{array}$ & $1,041,021.96$ & $754,440,90$ & $425,069.35$ & 0.00 & $522,068.90$ & $1,698,463.31$ \\
\hline System & $7,181,579,87$ & $4,815,028.25$ & $870,956.57$ & 0.00 & $1,383,471.24$ & $9,742,180.31$ \\
\hline
\end{tabular}

${ }^{20} \mathrm{Gm}$ Shaifullah et al., "Economic Analysis of Hybrid Renewable Model for Subtropical Climate," Int. J. of Thermal \& Environmental Engineering 1, no. 2 (2010): 57-65. 
Berdasarlan data NPC tersebut, nilai NPC yang berada pada nilai Rp 477.184,21 merupapkan nilai yang sangat terjangkau bagi masyarakat. Hal ini menunjukkan bahwa studi kelayakan telah dilakukan dengan baik. Dengan perhitungan NPC yang terjangkau ini diharapkan masyarakat dapat dengan mudah dan bijaksana dalam memelihara peralatan pembangkit listrik tenaga surya dengan baik dan bijak.

\section{Annualized Cost (AC)}

Total biaya tahunan yang dikeluarkan oleh sistem Hybrid Solar Cell-PV adalah sebesar Rp 477.184,21. Nilai annualized cost nantinya akan digunakan untuk mengetahui nilai Cost of Energy atau biaya pembangkitan listrik per kWh. Rincian biaya dari tiap komponen sebagai penyusun dari annualized cost dapat dilihat pada Tabel 4 .

Tabel 4. Rincian Biaya Tahunan Pada Tiap Komponen

\begin{tabular}{|c|c|c|c|c|c|c|}
\hline Componen & Capital (Rp) & $\begin{array}{l}\text { Replacemnet } \\
\text { (RP) }\end{array}$ & O\&M (Rp) & $\begin{array}{l}\text { Fuel } \\
\text { (Rp) }\end{array}$ & Salvage (Rp) & Total (Rp) \\
\hline $\begin{array}{l}\text { Canadian } \\
\text { Solar CS6P- } \\
260 P\end{array}$ & $174,572.25$ & 0.00 & $71,281.25$ & 0.00 & 0.00 & $145,853.50$ \\
\hline Grid & 0.00 & 0.00 & $186,292.13$ & 0.00 & 0.00 & $186,292.13$ \\
\hline $\begin{array}{l}\text { Luminous } \\
\text { Battery } \\
150 \mathrm{Ah}- \\
\text { RC } 18000\end{array}$ & $126,199.98$ & $198,892.66$ & $51,529.91$ & 0.00 & $42,192.57$ & $334,429.98$ \\
\hline $\begin{array}{l}\text { Luminous } \\
\text { solar nxg } \\
\text { hybrid } \\
\text { inverter } \\
750 \text { VA- } \\
12 \mathrm{~V}\end{array}$ & $50,990.56$ & $36,953.46$ & $20,820.43$ & 0.00 & $25,571.59$ & $83,192.86$ \\
\hline System & $351,762.79$ & $235,846.12$ & $42,660.55$ & 0.00 & $67,764.16$ & $477,184.21$ \\
\hline
\end{tabular}

\section{Cost of Energy (COE)}

Cost of energy atau biaya pembangkitan per kwh dihitung dengan membagi nilai biaya tahunan dengan total produksi energi.

$$
\begin{aligned}
C O E & =\frac{\text { Total } A C}{\text { Energi total produksi sistem }} \\
& =\frac{\operatorname{Rp} 541.953,95}{352 k W h} \\
& =\mathrm{Rp} 1.564,95 / \mathrm{kWh}
\end{aligned}
$$


Berdasarkan nilai Cost of Energy (CoE) yang terhitung, nilai Rp 1.564,95/kWh merupakan nilai yang sangat ekonomis. Nilai tersebut memiliki arti bahwa untuk membangkitkan energi listrik setiap kWhnya memerlukan biaya sebesar Rp 1.564,95. Tentu ini merupakan nilai yang sangat baik dan tidak mahal. Nilai CoE ini juga masih sangat terjangkau seperti nilai CoE dari PLN.

\section{Renewable Penetration}

Renewable penetration adalah salah satu parameter yang digunakan untuk mengetahui persentase dari kontribusi energi terbarukan dalam menghasilkan listrik di suatu sistem. Dalam sistem hybrid ini, yang tergolong sebagai energi terbarukan adalah solar cell dengan produksi energi yang dapat dilihat pada tabel 5.

Tabel 5. Energi Listrik Dari Komponen Energi Terbarukan

$$
\begin{aligned}
R P & =\frac{E_{\text {tot.RES }}}{E_{\text {tot.sys }}} * 100 \% \\
& =\frac{176}{351} \times 100 \% \\
& =50 \%
\end{aligned}
$$

\begin{tabular}{lc}
\hline \multicolumn{1}{c}{ Komponen } & Produksi $(\mathrm{kWh})$ \\
\hline Tiger World M120P36 & 176 \\
Total & 176 \\
\hline
\end{tabular}

Berdasarkan perhitungan renewable penetration di atas, dapat diketahui bahwa $50 \%$ energi listrik pada sistem bersumber dari energi terbarukan, yang dalam hal ini adalah solar cell. Berdasarkan nilai CoE sebesar 50\% dapat dianalisis bahwa energi terbarukan yang terpasang pada sistem memiliki kontribusi yang cukup baik.

Dengan nilai tersebut dapat dipastikan bahwa sistem pembangkit listrik tenaga surya yang terpasang sudah menyumbang pengurangan emisi gas $\mathrm{CO}_{2}$ sebesar $50 \%$. Nilai ini menunjukkan bahwa energi alternatif dan ramah lingkungan telah berhasil memberikan kontribusi yang nyata bagi pengurangan global warming.

\section{Penghematan yang didapatkan}

Penghematan yang didapatkan dari pengimplementasian solar cell di desa Wonosalam dapat dilihat dari jumlah energi yang didapatkan dari modul solar cell. Energi yang didapat dari solar cell selama 1 tahun adalah sebesar $176 \mathrm{kWh}$. Hal ini berarti penghematan yang didapat perhari adalah $176 \mathrm{kWh} / 365$ hari sama dengan 482,19 Wh sama dengan 0,48 kWh/hari. Sedangkan penghematan dalam rupiah adalah $176 \mathrm{kWh}$ dikali Rp1.467,28/kWh sam dengan Rp 258.241,28 per tahun.

Penghematan senilai Rp 258.241,28 per tahun merupakan nilai yang sangat baik 
dalam kategori perekonomian pedesaan. Dengan nilai penghematan tersebut, masyarakat desa dapat mengalokasikan dana ke pengeluaran lain yang lebih bermanfaat. Hal ini menunjukkan bahwa dengan adanya pembangkit energi listrik tenaga surya tidak hanya menumbuhkan masyarakat mandiri energi, namun juga masyarakat yang mandiri ekonomi.

\section{Kesimpulan}

Melalui pengabdian masyarakat ini maka terdapat beberapa hal yang telah dicapai, pertama Masyarakat memiliki pengetahuan mengenai Sumber Energi Alternatif Terbarukan Berbasis Tenaga Surya. Kedua Masyarakat mengetahui bagaimana behaviournya dalam menggunakan listrik, serta mengetahui nilai investasi penggunaan PLTS. Ketiga Terpasangnya PJU-PLTS untuk menunjang kegiatan sosial masyarakat, dan terakhir Adanya studi kelayakan dan supervisi pemasangan PLTS di dusun Wonosalam, sehingga didapatkan penghematan penggunaan PJU-PLTS sebesar 0,48 $\mathrm{kWh} /$ hari dan $\mathrm{Rp}$ 258.241,28 per tahun.

\section{Pengakuan}

Kegiatan pengabdian ini dibiayai oleh Departemen Penelitian dan Pengabdian Masyarakat Universitas Islam Indonesia (DPPM UII), melalui hibah internal pengabdian masyarakat dalam skema pengabdian unggulan.

\section{Daftar Referensi}

Arriaga, Mariano, Claudio A. Canizares, and Mehrdad Kazerani. "Renewable Energy Alternatives for Remote Communities in Northern Ontario, Canada." IEEE Transactions on Sustainable Energy 4, no. 3 (2013): 661-670.

Bahaj, Abubakr S., and Patrick A.B. James. "Electrical Minigrids for Development: Lessons from the Field." Proceedings of the IEEE 107, no. 9 (2019): 1967-1980.

Braid, Ralph M. "Partial Peak-Load Pricing of a Transportation Bottleneck with Homogeneous and Heterogeneous Values of Time." Economics of Transportation 16 (December 1, 2018): 29-41.

Briyan, Yuliarto. Pendekatan Praktis Pembangkit Energi Baru Dan Terbarukan. Bandung: ITB, 2017.

Enaganti, Prasanth K., Prabhat K. Dwivedi, Alok K. Srivastava, and Sanket Goel. "Analysis of Submerged Amorphous, Mono-and Poly-Crystalline Silicon Solar Cells Using Halogen Lamp and Comparison with Xenon Solar Simulator." Solar Energy 211 (November 15, 2020): 744-752.

Esch, Jim. "Keeping the Energy Debate Clean: How Do We Supply the World's Energy 
Needs?" Proceedings of the IEEE 98, no. 1 (2010): 39-41.

Fathoni, Hilman S., Abidah B. Setyowati, and James Prest. "Is Community Renewable Energy Always Just? Examining Energy Injustices and Inequalities in Rural Indonesia." Energy Research \& Social Science 71 (January 1, 2021): 101825.

Hartono, Djoni, Sasmita Hastri Hastuti, Alin Halimatussadiah, Atina Saraswati, Aria Farah Mita, and Vitria Indriani. "Comparing the Impacts of Fossil and Renewable Energy Investments in Indonesia: A Simple General Equilibrium Analysis." Heliyon 6, no. 6 (June 1, 2020): e04120.

Islam, Towhidul, and Nigel Meade. "The Impact of Attribute Preferences on Adoption Timing: The Case of Photo-Voltaic (PV) Solar Cells for Household Electricity Generation." Energy Policy 55. Special section: Long Run Transitions to Sustainable Economic Structures in the European Union and Beyond (April 1, 2013): 521-530.

Ismail, Ahmed G., Mahmoud A. El-Dabah, and Ibrahim A. Nassar. "Enhancement of Electrical Distribution Networks Performance Using the Load Management Methodology." Energy Reports 6 (November 1, 2020): 2066-2074.

Kapucu, Naim. "Community-Based Research in Generating Usable Knowledge for Public Policy and Administration." Sage Journals 48, no. 6 (2014): 683-710.

Kumar, Abhishek, Arvind R. Singh, Yan Deng, Xiangning He, Praveen Kumar, and Ramesh C. Bansal. "A Novel Methodological Framework for the Design of Sustainable Rural Microgrid for Developing Nations.” IEEE Access 6 (2018): 24925-24951.

Lawrence, Akvile, Magnus Karlsson, Therese Nehler, and Patrik Thollander. "Effects of Monetary Investment, Payback Time and Firm Characteristics on Electricity Saving in Energy-Intensive Industry." Applied Energy 240 (April 15, 2019): 499512.

Maulidia, Martha, Paul Dargusch, Peta Ashworth, and Fitrian Ardiansyah. "Rethinking Renewable Energy Targets and Electricity Sector Reform in Indonesia: A Private Sector Perspective." Renewable and Sustainable Energy Reviews 101 (March 1, 2019): 231-247.

Shaifullah, Gm, Shawkat Ali, Aman Than Oo, and Denis Jarvis. "Economic Analysis of Hybrid Renewable Model for Subtropical Climate." Int. J. of Thermal \& Environmental Engineering 1, no. 2 (2010): 57-65.

Singh, Madalsa, and P. Balachandra. "Microhybrid Electricity System for Energy Access, Livelihoods, and Empowerment." Proceedings of the IEEE 107, no. 9 (2019): 19952007.

Sukandarrumidi, Herry Zadrak Kotta, and Djoko Wintolo. Energi Terbarukan Konsep Menuju Kemandirian Energi. Yogyakarta: Gadjah mada university press, 2018. 
Sulandari, Winita, Subanar, Muhammad Hisyam Lee, and Paulo Canas Rodrigues. "Indonesian Electricity Load Forecasting Using Singular Spectrum Analysis, Fuzzy Systems and Neural Networks." Energy 190 (January 1, 2020): 116408.

Supapo, Santiago, and Pacis. "Electric Load Demand Forecasting for Aborlan-NarraQuezon Distribution Grid in Palawan Using Multiple Linear Regression." In 9th International Conference on Humanoid, Nanotechnology, Information Technology, Communication and Control, Environment and Management (HNICEM), 2017.

Tiihonen, Armi, Virpi Siipola, Katja Lahtinen, Heikki Pajari, Petri Widsten, Tarja Tamminen, Tanja Kallio, and Kati Miettunen. "Biocarbon from Brewery Residues as a Counter Electrode Catalyst in Dye Solar Cells." Electrochimica Acta 368 (February 1, 2021): 137583.

Ubilla, Karen, Guillermo A. Jiménez-Estévez, Roberto Hernádez, Lorenzo ReyesChamorro, Claudia Hernández Irigoyen, Bernardo Severino, and Rodrigo PalmaBehnke. "Smart Microgrids as a Solution for Rural Electrification: Ensuring LongTerm Sustainability through Cadastre and Business Models." IEEE Transactions on Sustainable Energy 5, no. 4 (2014): 1310-1318.

Unggul, Wibawa. Pendekatan Praktis Pembangkit Energi Baru Dan Terbarukan. Bandung: UB Press, 2017.

Winstead, Christopher, Mahabir Bhandari, James Nutaro, and Teja Kuruganti. "Peak Load Reduction and Load Shaping in HVAC and Refrigeration Systems in Commercial Buildings by Using a Novel Lightweight Dynamic Priority-Based Control Strategy." Applied Energy 277 (November 1, 2020): 115543.

Zare Oskouei, Morteza, Behnam Mohammadi-Ivatloo, Mehdi Abapour, Amjad AnvariMoghaddam, and Hasan Mehrjerdi. "Practical Implementation of Residential Load Management System by Considering Vehicle-for-Power Transfer: Profit Analysis." Sustainable Cities and Society 60 (September 1, 2020): 102144. 